\title{
和歌山県紀ノ川の水質特性から算定した COD及びCOD負荷量 \\ COD VALUES AND COD LOADS CALCULA'IED BY WATER QUALITY CHARACTERISTICS OF THE KINOKAWA RIVER, WAKAYAMA PREFECTURE
}

\author{
高野芳隆 1 - 井伊博行 2 - 石塚正秀 3 - 平田健正 4 . 平井秀輝 5 \\ Yoshitaka TAKANO, Hiroyuki II, Masahide ISHIZUKA, Tatemasa HIRATA, Hideki HIRAI \\ 1学生会員 和歌山大学大学院 システム工学研究科（广640-8510 和歌山市栄谷930） \\ 2正会員 博（理） 和歌山大学教授 システム工学部（同上） \\ 3正会員 博（工） 和歌山大学助手 システム工学部（同上） \\ 4正会員 工博 和歌山大学教授 システム工学部（同上） \\ 5 国土交通省近畿地方整備局和歌山河川国道事務所（テ640-8272 和歌山市砂山南3-1-15）
}

\begin{abstract}
A COD value and COD load calculation method was determined using the intensive measurement results of COD values and flow rates in the Kinokawa river. For 4 years, hourly measurements lead COD values changed with flow rate. The relation between flow rates and COD values was analyzed. Using this relation, past COD values and COD loads could easily be calculated from flow rate. The used data has no data of high flow rate condition because sampling is difficult at the condition of high flow rate. With the exclusion of high flow rate (more than $1400 \mathrm{~m}^{3} / \mathrm{s}$ ), the calculation results were in good agreement with actual measurements. The estimated past COD loads of the Kinokawa River were very changeable and maximum COD loads reached 8 times that of minimum values for past 29 years.
\end{abstract}

Key words: $C O D$, discharge, the amount of load

\section{1. はじめに}

水は自然環境の根幹となって多様な生態系を支え るとともに, 人間社会の存立を構成する重要かつ基 本的な資源である. また, 消費すれば減少する石炭 や石油と異なり，国土を循環する資源でもある。こ のような水循環において, 環境に負荷を与える物質 がどのように移動し，どのような影響を与えるのか を把握することは水資源の保全および改善に重要と なる1),2). 現在, 日本の水質は改善されつつあるが, 未だ環境基準を達成できない流域もある．本研究の 対象流域である紀ノ川においても, 船戸における生 物化学的酸素要求量(BOD)75\% 值は環境基準を達 成しておらず, 紀ノ川の水質污濁の原因と今後の水 質改善のために, 水質特性を把握することが必要で ある. 本研究以前にも紀ノ川の物質負荷量の推定と 土地利用との関係 ${ }^{3), 4}$ について研究がなされてきた が, 詳細な水質污染の原因がいまだ解明されていな い. そこで本研究は, 河川の長期の環境に負荷を与 える物質の移動や影響5),6),7)を把握するために, 過去 の負荷量を推定することを目的とする. しかし, 過 去の負荷量（濃度 $\times$ 量）を推定する際に, 必要とな る水質データの測定頻度が低く,1ヶ月に 1 回程度の 測定しか行われていない。したがって，これらのデ 一夕から物質量を算定することは, 大きな誤差が生
じると考えられる. 過去の負荷量を推定するための 方法として, 単純に過去の既存のデータから関係式 を導く方法ではなく, 現在の1時間毎のデータから流 量と水質の関係，および水質の時間変化などの水質 特性を明確にし, 測定頻度の少ないデータでも精度 の高い解析を行う方法を考察する.

\section{2. 調查地域, 測定概要}

対象流域となる紀ノ川を図-1に示す．紀ノ川は日 本最多雨地帯の奈良県南部の大台ケ原を水源とし, 北西に流れた後, 西南西へ進路を変え, 中央構造線 に沿って, 紀伊水道に注ぐ流域面積 $1,558 \mathrm{~km}^{2}$, 幹川 流路延長 $136 \mathrm{~km}$ の一級河川である. 主な支川には左 支川である秋野川, 大和丹生川, 紀伊丹生川, 貴志 川，また右支川である高見川，橋本川などがある. また, 紀ノ川は, 流域外の奈良県で約 37 万人, 五條 市, 橋本市, 岩出町, 海南市, 和歌山市の紀ノ川流 域内の市町村では約 64 万人, 計約 101 万人の給水人口 をもつ重要な水源である8).

紀ノ川は, 最上流部では, 奈良県東部に集落と田 畑がわずかに散在する程度で, 大部分が針葉樹によ る森林地帯となっている. 中流部から下流部にかけ ては，五條市や橋本市などを中心に宅地や農地が多 く分布する. 橋本市から和歌山市の間では, 桃, 柿, 


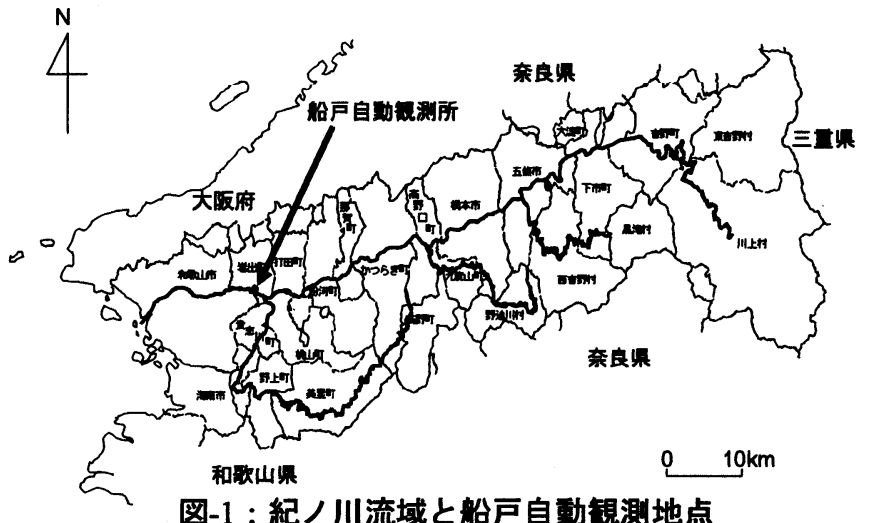

みかん等の果樹園が主に分布する ${ }^{8)}$.

本研究ではこの紀ノ川の河口からの距離 $16.7 \mathrm{~km} の$ 所に位置する治水計画基準地点の船戸の自動観測所 (船戸第2水位観測所, 船戸流量観測所, 船戸雨量観 測所)における観測データをもとに解析を行った. 自 動観測データは1999年〜2002年の4年間の 1 時間毎 に計測された流量と, 化学的酸素要求量(COD), 電 気伝導度(EC), 濁度(TB)の3つの水質項目, 1970年〜 2002年(1977年と 1980年を除く)の定期観測時のCOD 濃度, 流量データを用いた。

\section{3. 結果と考察}

\section{（1） CODの流量依存特性}

a）測定頻度の違いによるCODと流量の関係

本研究では, 紀ノ川において未だに環境基準を達 成していない生物化学的酸素要求量(BOD)之同様, 水質污濁の指標の1つである化学的酸素要求量 (COD)の流量依存特性について考える. COD と流量 の関係を図-2と図-3に示す。図-2は1970年から2002 年(1977年と 1980年を除く)までの29年間の定期観測 データから得られた図である，定期観測データの COD濃度は1カ月に1回測定されたもので, 流量デー 夕は1日1回観測されたものであるが, COD濃度測定 日の值を用いている. 図から，多くのデータが流量 (Q) $400 \mathrm{~m}^{3} / \mathrm{s}$ 以内, COD濃度 $10 \mathrm{mg} / 1$ 以内に収まってお り，流量が増加すると図の2つの矢印方向に分かれて COD濃度も增加するようにみられる。図-3は, 1999 年から 2002年までの4年間の自動観測データからの 図である. 自動観測データは, COD濃度, 流量共に 1時間毎に観測されたものである. 図-3は, 図-2に比 べてデータの数も格段に多くなり，定期観測データ では, $400 \mathrm{~m}^{3} / \mathrm{s}$ までの流量に対応するCOD䀼度が観測 されていなかったが，1 時間毎のデータでは流量が $400 \mathrm{~m}^{3} / \mathrm{s}$ 以上の高流量時のCOD濃度も観測されてい る. しかしながら，自動観測でもCOD濃度が $20 \mathrm{mg} / 1$ を超えるものについては観測できないというセンサ 一の問題があり, 流量が $1400 \mathrm{~m}^{3} / \mathrm{s}$ 以上のデータでは COD濃度が測定不能な結果が多いため, 流量が $1400 \mathrm{~m}^{3} / \mathrm{s}$ 以上のデータについては省いてある. また, この図の $200 \mathrm{~m}^{3} / \mathrm{s}$ 以上の搪がりは図中の破線の楕円 軌道の集合とみることもできる.

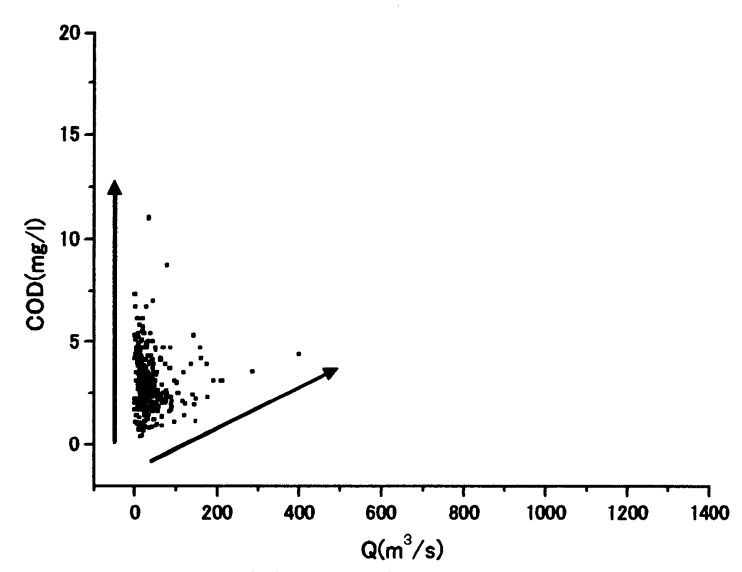

図-2:CODと流量(Q)の関係(1970年 2002年 : 1回/月)

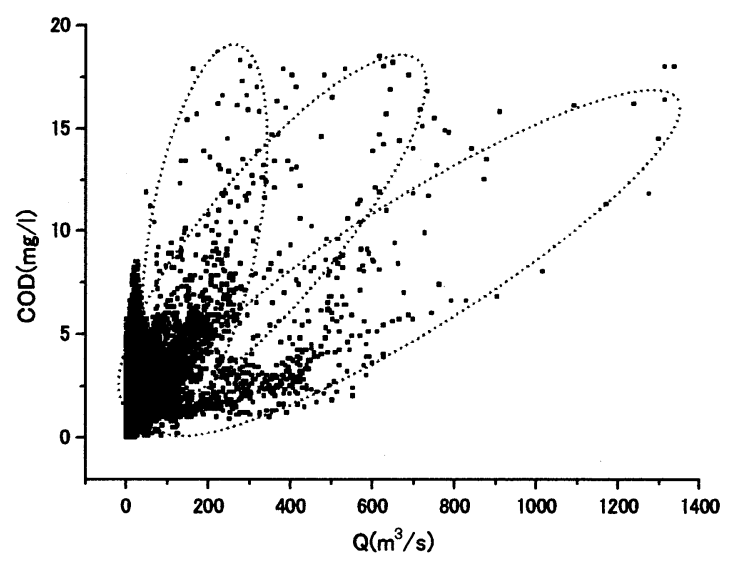

図-3:CODと流量(Q)の関係(1999年〜2002年 : 1回/時)

\section{b）流量の割合}

このように, 自動観測によって流量が $400 \mathrm{~m}^{3} / \mathrm{s}$ 以上 の高流量時の水質データが得られるようになった. 今までの定期観測では天候や人的要因により高流量 時の採水は行われていなかった。この定期観測から 自動観測に変わることによって，新たに得られた高 流量時のデータが全体の流量に占める割合を, 流量 のデータ数と年間の総流量から計算した結果を, 表 -1, 表-2に示す. 表-1の流量データ数の割合は, どの 年も $100 \mathrm{~m}^{3} / \mathrm{s}$ 末満の基底流量時のデータが全体の 90\%以上を占めている. しかし，表-2の年間の総流 量の割合についてみると，1999年と2001年の流量が $100 \mathrm{~m}^{3} / \mathrm{s}$ 未満の基底流量時の割合は $50 \%$ 以下になっ ている.また，2001年においては流量が $1400 \mathrm{~m}^{3} / \mathrm{s}$ 以 上の時の割合が $15 \%$ 高くなっており，この年は高 流量時の割合が他の年よりも多い. 逆に, 2002年は 流量が $100 \mathrm{~m}^{3} / \mathrm{s}$ 未満の時の割合が $72.7 \%$ と他の年に比 べて高く, 流量が $1400 \mathrm{~m}^{3} / \mathrm{s}$ 以上の時が観測されなか った.よって，この年は基底流量時の割合が多い年 である.

\section{c) $\mathrm{COD}$ と流量の関係}

流量が $100 \mathrm{~m}^{3} / \mathrm{s}$ 以上になる増减の変化を 1 つのイベ ントとし，1999年の流量変化を16のイベント， 2000 年の流量変化を12のイベント，2001年の流量変化を 
表-1 : 流量のデータ数による割合(1999年〜2002年)

\begin{tabular}{|c|c|c|c|c|c|}
\hline 添 & 1999年 & 2000年 & 2001年 & 2002年 & 1999年-2002年 \\
\hline$Q<100 \mathrm{~m}^{3} / \mathrm{s}$ (回) & 7889 & 8355 & 8009 & 8404 & 32657 \\
\hline $100 \mathrm{~m}^{3} / \mathrm{s} \leq Q<400 \mathrm{~m}^{3} / \mathrm{s}$ (回) & 682 & 350 & 603 & 313 & 1948 \\
\hline $400 \mathrm{~m}^{3} / \mathrm{s}<\mathrm{Q}<1400 \mathrm{~m}^{3} / \mathrm{s}$ (回) & 179 & 72 & 114 & 43 & 408 \\
\hline 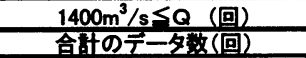 & $\begin{array}{r}10 \\
8760\end{array}$ & $\begin{array}{r}7 \\
8784\end{array}$ & $\begin{array}{r}34 \\
8760 \\
\end{array}$ & $\begin{array}{r}0 \\
8760\end{array}$ & $\begin{array}{r}51 \\
35064\end{array}$ \\
\hline
\end{tabular}

表-2: 年間の総流量による割合(1999年〜2002年)

\begin{tabular}{|c|c|c|c|c|c|}
\hline 法 $\mathrm{f}(\mathrm{Q})$ & 1999年 & 2000年 & 2001年 & 2002年 & 1999年-2002年 \\
\hline$Q<100 \mathrm{~m}^{3} / \mathrm{s}$ & 666465796.4 & 740740868 & 795598740 & 710985924 & 2913791328 \\
\hline $100 \mathrm{~m}^{3} / \mathrm{s} \leq \mathrm{Q}<400 \mathrm{~m}^{3} / \mathrm{s}$ & 491209440 & 235502539.1 & 358779780 & 178539948 & 1264031707 \\
\hline $400 \mathrm{~m}^{3} / \mathrm{s} \leq \mathrm{Q}<1400 \mathrm{~m}^{3} / \mathrm{s}$ & 427402166.6 & 164738329.6 & 305324712 & 87994188 & 1075800094 \\
\hline $1400 \mathrm{~m}^{3} / \mathrm{s} \leq Q$ & 52737663.49 & 43013102.93 & 259100424 & 0 & 264510492.2 \\
\hline 然浾 $\left(\mathrm{m}^{3} /\right.$ year $)$ & 1637815066 & 1183994840 & 1718803656 & 977520060 & 5518133622 \\
\hline
\end{tabular}

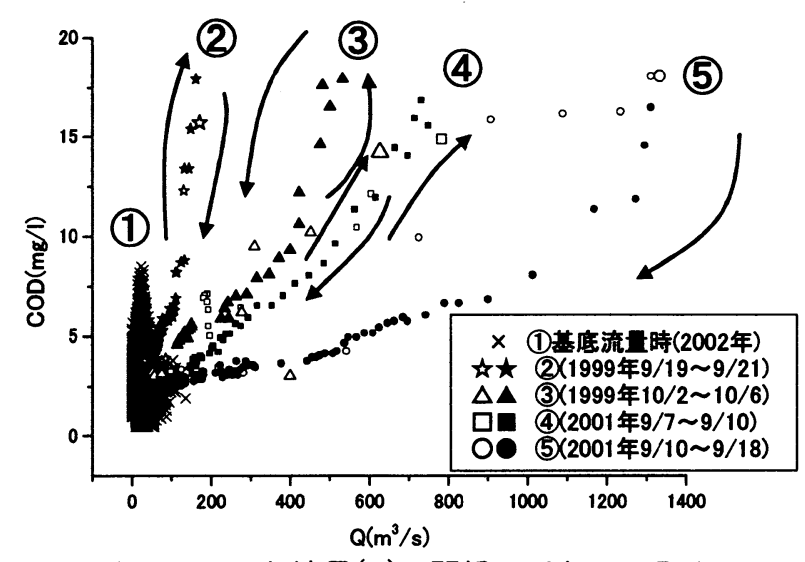

図-4 CODと流量(Q)の関係のパターン分け

（1999年～2002年）

12のイベント, 2002年の流量変化を8のイベントに分 離させることができる．そして，各イベント毎に CODと流量の関係についてみた。その代表的な結果 を図-4に示すように, (1)〜 (5)の5つのパターンに分け られた. (1)の変化は, 基底流量時 $\left(100 \mathrm{~m}^{3} / \mathrm{s}\right.$ 末満)にみ られる関係で, COD濃度は $10 \mathrm{mg} / 1$ 末満に収まってい る. (2)の変化は, 流量が $100 \mathrm{~m}^{3} / \mathrm{s}$ 以上 $200 \mathrm{~m}^{3} / \mathrm{s}$ 末満の データの時にみられる関係, (3)の変化は流量が $200 \mathrm{~m}^{3} / \mathrm{s}$ 以上 $600 \mathrm{~m}^{3} / \mathrm{s}$ 未満のデータの時にみられる関 係，(4)の変化は流量が $600 \mathrm{~m}^{3} / \mathrm{s}$ 以上 $800 \mathrm{~m}^{3} / \mathrm{s}$ 未満のデ 一夕の時にみられる関係, (5)の変化は流量が $800 \mathrm{~m}^{3} / \mathrm{s}$ 以上のデータの時にみられる関係で，㐫, $\triangle, \square, \bigcirc の 4$

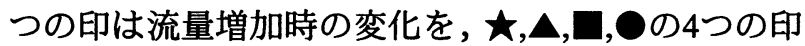
は流量減少時の変化を示している．また，大きな々， $\triangle, \square, \bigcirc$ の印は各イベントの最大流量時のCOD濃度 を示している.したがって，各イベントは，その最 大流量によって(2)〜(5)のいずれかのヒステリシス ${ }^{12)}$ を描くことになる。また，それそれのヒステリシス は基底流量時の座標からスタートし, 基底流量時の 座標に戻るブーメラン型の変化をする．この(2)〜(5) のブーメラン型の変化において(3)の変化のみ反時計 回りになっている.これは(2), (4)同様, 流量増加時 と減少時の濃度の差が非常に小さく, また流量増加 時の $\Delta$ の数と流量減少時の $\Delta$ の数では $\Delta$ の数が少な いため, (3)の変化だけが見かけ上反時計回りの結果 となったと考えられる. 逆に, (5)の変化については 流量増加時と減少時の濃度の差が大きく, 明確に時
計回りの変化がみられた.そして，これらのブーメ ラン型の変化の傾きは, イベントの最大流量が大き くなるにつれて，小さくなることが判った。また， そのヒステリシスの同じ流量における濃度差が, 各 イベントの最大流量が増加すると, 大きくなること が判った.

d) EC, TBと流量の関係

ここで, CODの流量依存特性と他の水質項目との 違いをみてみる。COD濃度と同様に，1時間毎に測 定を行っている溶存成分の総量の目安となる電気伝 導度(EC)と，浮遊成分を測定している濁度(TB)の流 量依存特性との違いについて考える。図-5,図-6に 1999年から2002年の4年間の1時間毎のEC, TBと流 量の関係9),10),11) を示す.図-5のECと流量(Q)の関係に ついてみると, 基底流量時になるとECの值は増加ラ イン1に沿って移動する.そして, 流量が増加すると 減少ライン2へ移動し, 流量が減少すると平行ライン 3へと移動する.したがって, 流量が増加して減少す るイベントにおいて $1 \rightarrow 2 \rightarrow 3$ と変化していく.また， イベントが続くと基底流量時の上昇がないので $4 \rightarrow 5$ とECは最低值を維持しながら変化する. 以上のこと から溶存成分であるECは流量が増加すると雨水の 流入によって一般に希釈されるので減少する。しか し,雨水の流入がなく基底流量時の期間が長く続く と, ECの值は大きくなる.

図-6から，CODと流量の関係と同様に，流量が増 加するとTB濃度も増加しており, その増加の傾きに よって, A,B,Cの3つのタィプに分けられる。流量(Q) 一 TBの分布をイベント毎に, 流量増加時のプロット (図-6の $\Delta, \bigcirc ， 认)$, 流量減少時のプロット(図-6 のム，○，丸)からなるヒステリシスが観測された。

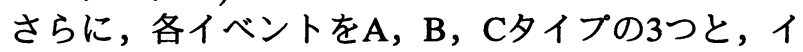
ベント以外の基底流量時を含めて4つにTB夕イプに 分類した. A夕イプはイベントの最大流量が $100 \mathrm{~m}^{3} / \mathrm{s}$ 末満の時にみられ， $\triangle$ は流量増加時を， $\Delta$ は流量減 少時の変化を表している. B夕イプはイベントの最 大流量が $100 \mathrm{~m}^{3} / \mathrm{s}$ 以上 $400 \mathrm{~m}^{3} / \mathrm{s}$ 末満の時にみられ，○ は流量増加時を, ○は流量減少時の変化を表してい る.Cタイプはイベントの最大流量が $400 \mathrm{~m}^{3} / \mathrm{s}$ 以上の 時にみられ，々は流量増加時を，丸は流量減少時の 変化を表している. また, 十は, 基底流量時のTB(流 量が $15 \mathrm{~m}^{3} / \mathrm{s}$ 以下)を示している.さらに，図中の大き

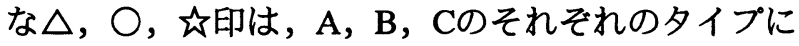




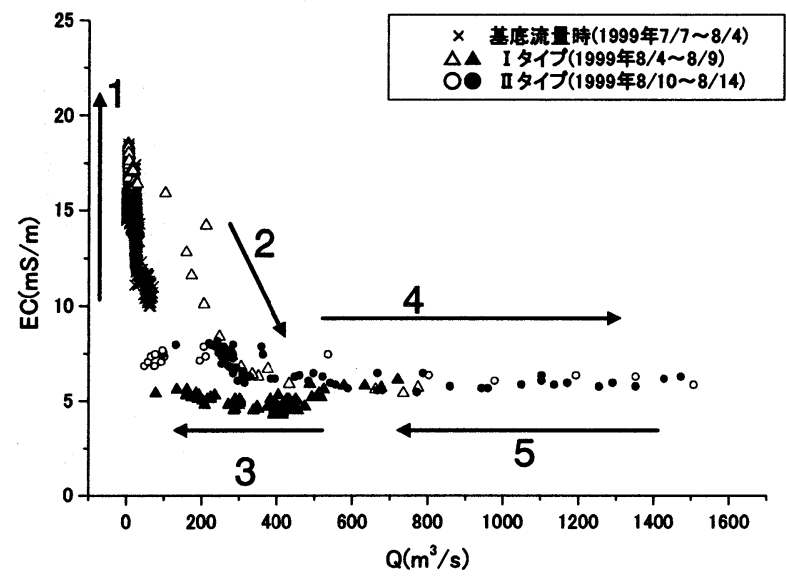

図-5 : ECと流量(Q)の関係におけるタイプ分け （1999年～2002年）

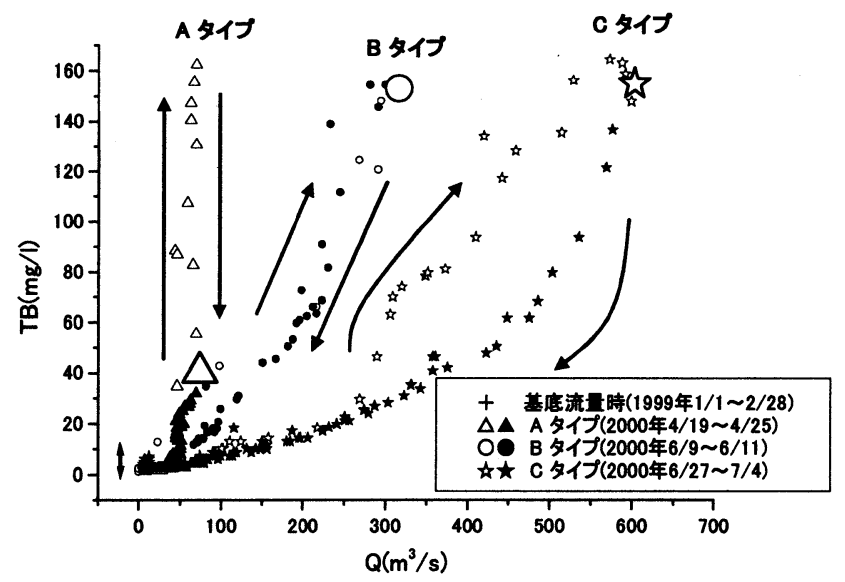

図-6 : TBと流量(Q)の関係におけるタイプ分け （1999年～2002年）

おける各イベントの最大流量時を示し，矢印は，各 イベントの時間変化を示している.基底流量時では， わずかな流量の変動によってTB濃度の増減が観測 される.濃度変化の範囲は2〜 $5 \mathrm{mg} / 1$ ある. 次に， 流量変動のあるA， B, C夕イプでは，流量の増加や 減少に伴ってTBも増加，減少をしているが，同一流 量でも, 流量増加時は, TBは高く, 流量減少時は, TBは低いヒステリシスが観測された。また，イベン 卜の最大流量が $\Delta, O ，$ 々(図-6のそれそれ拡大され た印)と順に増加すると, その流量(Q) - TBの勾配も $\mathrm{A}, \mathrm{B}, \mathrm{C}$ タプの順で，なだらかになっている。そ の上, イベントの流量増加時のTB濃度(図-6の $\Delta, \bigcirc$,

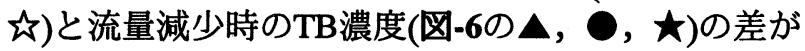
A，B，Cタイプの順に広がっているようにみえる. また, 各イベントの最大TB濃度は, 各イベントの最 大流量とは無関係である. 以上のことから, 浮遊成 分量であるTBは, 巻き上げのきっかけとなる流量に 達していない基底流量時は, 常にTBが低くなってい るが流量が増加すると, 巻き上げによりTBが増加す ることが考えられるが, それと同時に, 希釈も起こ るので, 単純に流量とTBは比例しなかったことが考 えられる.そして, 各イベントは, COD同様その最 大流量によって，A，B，Cタイプのいずれかのヒス
表-3：最大流量によって分けられる5つのパターンの推定式

\begin{tabular}{|c|c|c|c|}
\hline & パターン & 最大流 $\mathrm{f}^{-}\left(\mathrm{m}^{3} / \mathrm{s}\right)$ & L-Q式 \\
\hline \multirow{5}{*}{ COD推定式 } & (1) & 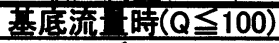 & $L=2008.4 * Q^{\wedge} 1.1$ \\
\hline & (2) & $100 \leqq Q<200$ & $L=10.0 * Q^{\wedge} 2.4$ \\
\hline & (3) & $200 \leqq Q<600$ & $\mathrm{~L}=21.9 * \mathrm{Q}^{\wedge} 2.0$ \\
\hline & (4) & $600 \leqq Q<800$ & $L=18.3 * Q^{\wedge} 2.0$ \\
\hline & (5) & $800 \leqq Q$ & $L=0.7 * Q^{\wedge} 2.4$ \\
\hline
\end{tabular}

テリシスを描くのであるが, それぞれのヒステリシ スは基底流量時の座標からスタートし, 基底流量時 の座標に戻るブーメラン型の変化をする.そして, その傾きは, イベントの最大流量が大きくなるにつ れて，小さくなることが判った. また，そのヒステ リシスの同じ流量における濃度差が, 各イベントの 最大流量が増加すると，その差も大きくなっている ことが判った．このようにCODは，希釈が支配する ECとは全く異なるパターンを示した.一方, CODと TBと共に流量が増加すると濃度も増加し, その変化 の関係も各イベントの変化パターンも共通し, COD は, TBと同様に浮遊成分の影響を強く受けているこ とが判る。

\section{（2）濃度推定と負荷量算定}

a) 最大流量で分けられる5つのパターンの濃度推定 今までのCODと流量の水質特性を踏まえて負荷 量算定のための濃度推定を考えていく.CODと流量 との間にある5つのパターンから, 負荷量 $(\mathrm{L})$ と流量 (Q)の関係図を作成し, L-Q式すなわちCOD推定式を 導いた。.CODには基底流量時の(1)と，(2)，(3)，(4), (5)の5つのパターンがあり,それぞれのパターンはイ ベントの最大流量によって分類される．(1)のパター ンは基底流量時(最大流量が $100 \mathrm{~m}^{3} / \mathrm{s}$ 未満)のイベント， (2)のパターンでは最大流量が $100 \mathrm{~m}^{3} / \mathrm{s}$ 以上で $200 \mathrm{~m}^{3} / \mathrm{s}$ 未満のイベント, (3)のパターンでは最大流量が $200 \mathrm{~m}^{3} / \mathrm{s}$ 以上で $600 \mathrm{~m}^{3} / \mathrm{s}$ 未満のイベント, (4)のパター ンでは最大流量が $600 \mathrm{~m}^{3} / \mathrm{s}$ 以上で $800 \mathrm{~m}^{3} / \mathrm{s}$ 未満のイベ ント, (5)のパターンでは最大流量が $800 \mathrm{~m}^{3} / \mathrm{s}$ 以上のイ ベントに適用される. COD推定式の5つのパターン を表-3と図-7に示す.そして，この推定式を基底流 量時, 各イベントごとに適用し，1999年から2002年 の4年間分の各年間COD負荷量を算定した。その結 果を表-4に示す.この表の真値とは, 自動観測所で 測定された1時間毎のCODデータと流量から求めた 負荷量であり，この真值に近い負荷量が求まればそ の推定式の精度が高いことを表す。また，従来の定 期観測時の水質データだけから求めた年間負荷量も 共に示した.これらの結果を見ると新しい推定式に よる值は全体的に真値より值が大きくなり，2002年 以外の $3 \supset$ 年において，真值より約 2 倍以上の過大 評価が見られ，この推定式は誤差が大きいことが判 る.これは前節でも述べたように，この推定式が流 量が $1400 \mathrm{~m}^{3} / \mathrm{s}$ 未満の現象から導き出したからである.

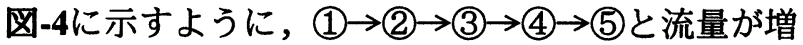
加するとCODと流量の関係(ヒステリシス)の傾きは なだらかなものとなる。つまり, 流量が $1400 \mathrm{~m}^{3} / \mathrm{s}$ 以 上の負荷量を $1400 \mathrm{~m}^{3} / \mathrm{s}$ 未満の式で算定するので, 負 


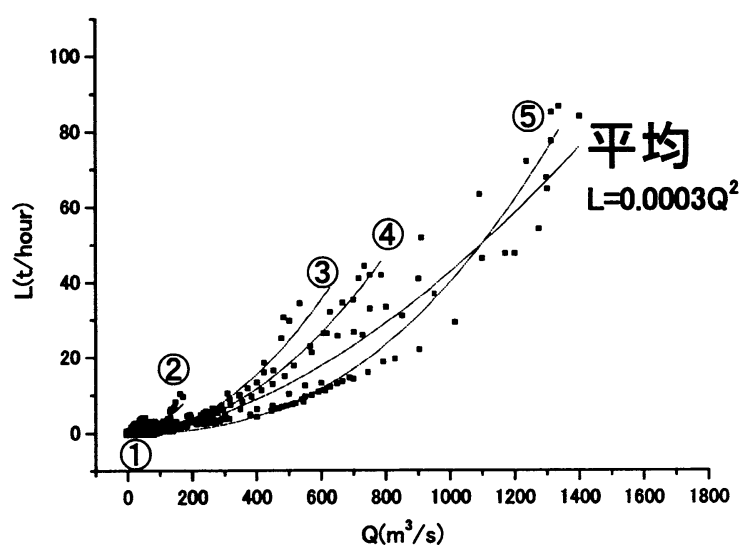

図-7：CODと流量の関係による推定式(L-Q式)

表·4:ヒステリシスから求めた推定式によるCOD負荷量結果 （1999年～2002年）

\begin{tabular}{|c|c|c|c|c|}
\hline & 1999年 & 2000年 & 2001年 & 2002年 \\
\hline I便( $\mathrm{t} /$ year) & 6613.46 & 4815.44 & 7381.10 & 3670.94 \\
\hline 定期得覩測( $t$ /year) & 1331.60 & 1134.52 & 2092.28 & 2748.33 \\
\hline 推定後( $\mathrm{t} /$ year $)$ & 13505.71 & 7583.33 & 18853.81 & 4681.34 \\
\hline 薑差 $(\%)$ & 104 & 57 & 155 & 28 \\
\hline
\end{tabular}

表·5 : 平均推定式から導いたCOD負荷量結果 （1999年～2002年）

\begin{tabular}{|c|c|c|c|c|}
\hline & 1999年 & 2000年 & 2001年 & 2002年 \\
\hline 具值 $(\mathrm{t} /$ year $)$ & 6613.46 & 4815.44 & 7381.10 & 3670.94 \\
\hline 定期得視測( $\mathrm{t} /$ year) & 1331.60 & 1134.52 & 2092.28 & 2748.33 \\
\hline 推定後( $\mathrm{t} /$ year) & 7903.38 & 4120.10 & 10931.16 & 2178.20 \\
\hline 煨差 $(\%)$ & 20 & -14 & 48 & -41 \\
\hline
\end{tabular}

荷量が多くなるのである．そして，2002年のみ真値 に近かったのは, 流量が $100 \mathrm{~m}^{3} / \mathrm{s}$ 未渵のデータが占め る割合が高く, $1400 \mathrm{~m}^{3} / \mathrm{s}$ 以上のデータが観測されな かったためだと考えられる. また，定期観測時の水 質データだけから求めた年間の負荷量はどの年も大 幅に過小評価されている.これは図-2, 図-3の違い のように, 高流量時の変化を考慮していないからだ と考えられる.

\section{b）負荷量平均からの推定}

負荷量平均から推定式を導き推定後の負荷量誤差 について検討した。この方法は図-3から導いた方法 である。この図をみると判るように，同じ流量にお いてCODの值が大きな広がりをみせている. その広 がりは最大で約1〜20mg//る.そこで, 1999年から 2002 年の 4 年間の 1 時間毎のCOD濃度データと流量 データから 1 時間毎の負荷量を求め, 同じ流量のと きの負荷量を平均させてその平均値から推定式を導 いた.この式を図-7に示す.この図から負荷量平均 の方法は,ヒステリシスの関係によって導き出した5 つの推定式の平均的な式になっていることが判る. この平均推定式を用いて年間負荷量を求めた結果を 表-5に示す.この表の誤差の結果は, 正の值は真値 より過大評価していることを表しており，逆に負の 值は真値より過小評価していることを表している.

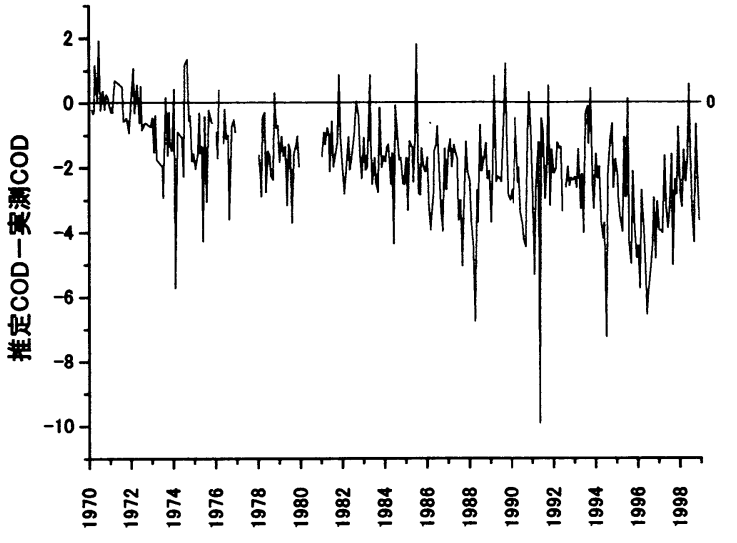

図-8 : 推定COD浱度と実測COD浱度の差の変化 （1970年～1998年）

表-6 : 推定COD漶度と実測COD濃度の誤差の標準偏差 （1999年～2002年）

\begin{tabular}{|c|r|r|r|r|}
\hline 流 (Q) & 1999 年 & 2000 年 & 2001 年 & 2002 年 \\
\hline$Q<100 \mathrm{~m} 3 / \mathrm{s}$ & 0.959 & 1.084 & 2.342 & 1.649 \\
\hline $100 \mathrm{~m} 3 / \mathrm{s} \leqq \mathrm{Q}<400 \mathrm{~m} 3 / \mathrm{s}$ & 2.769 & 3.494 & 2.150 & 2.750 \\
\hline $400 \mathrm{~m} 3 / \mathrm{s} \leqq \mathrm{Q}<1400 \mathrm{~m} 3 / \mathrm{s}$ & 4.174 & 5.123 & 4.029 & 4.805 \\
\hline $1400 \mathrm{~m} 3 / \mathrm{s} \leqq \mathrm{Q}$ & 0.919 & 0.611 & 6.106 & 0.000 \\
\hline
\end{tabular}

この結果から，2001年と2002年の真值に対しての誤 差が他の1999年, 2000年に比べて大きくなっている. 2001 年は表-1,表-2に示すように流量が $1400 \mathrm{~m}^{3} / \mathrm{s}$ 以上 の総流量に対する割合が他の年に比べて15\%(他の 年は数\%以下)と高いために, 負荷量に対する影響も 大きいと考えられる. また，図-7に示す平均負荷量 から求めた推定式は, 流量が $1400 \mathrm{~m}^{3} / \mathrm{s}$ 以上の時の COD濃度を考慮していない. したがって, 高流量時 の負荷量がうまく表されていないために誤差が $48 \%$ に達したと考えられ，2002年の流量デー夕は，表-1， 表-2,図-7から, 流量が $100 \mathrm{~m}^{3} / \mathrm{s}$ 未満の基底流量時のデ 一タが73\%(他の年は $41 〜 63 \%$ )と多いため誤差がー 41\%と大きくなったと考えられる.したがって, ヒ ステリシスの推定式から計算した年間負荷量よりも 平均負荷量から求めた推定式の方が, 数値的にみて 格段に精度が上がっていることが判る。

\section{（3）過去の負荷量算定}

以上の結果から,1999年から2002年の 4 年間のデー 夕から求めた平均負荷量推定式を使って, 過去の COD濃度を推定し, 過去の実測值との差をみた。そ の結果を図-8に示す. 過去のデータは1970年〜1998 年(1977年と1980年を除く)のデータで, 年に12回観 測されている．また，推定値と実測值が近いほど, 差は小さくなる.1970年から1972年など所々誤差が 小さいが, 全体の変化をみると, 年々マイナスの方 へ差が広がっているようにみられ，推定値が過小評 価されていることになる。これは，定期観測と自動 観測の両方のデータが存在する1999年のCOD濃度 $(\mathrm{mg} / \mathrm{l})$ では,定期観測と自動観測のデータは定期観測 時の方が平均 $1.3 \mathrm{mg} / 1$ 高く, 最高で $3.0 \mathrm{mg} /$ 違う場合も みられ，この影響が推定値を過小評価させた原因と 


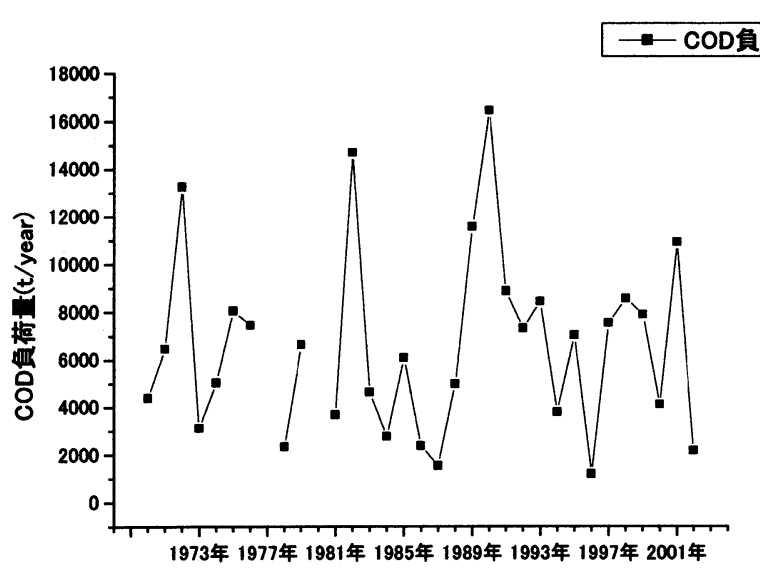

図-9:過去の COD 負荷量の変動(1970 年〜2002 年)

考えられる.また,この定期観測と自動観測の差は， それぞれの観測方法による違いといえる. そこで， 推定式を導いた年のCOD濃度のばらつきをみるた めに1999年から 2002年の各年毎に標準偏差を求めた. その結果を表-6に示す．この表をみると，流量が多 くなるにつれてばらつきも大きくなっている.しか し，1999年と 2000 年の流量が $1400 \mathrm{~m}^{3} / \mathrm{s}$ 超えるCOD 濃度の誤差のばらつきはデータ数が少ないため非常 に小さい。したがって表-5に示すように，1999年と 2000年の負荷量推定において高流量時のCODのば らつきが小さかったため誤差が小さくなったと考え られる. 最後に, 1999年から2002年の水質特性が変 化していないと仮定して, 過去の推定を行った結果 を図-9に示す．この図から，年によってCOD負荷量 が最大 8 倍も異なる.

\section{4. まとめ}

過去の負荷量を推定する場合, 従来の定期観測デ 一夕のみを使った負荷量算定方法では, 高流量時の 水質データが考慮されておらず, 著しく過小評価さ れた負荷量となる(表-4,表-5). そこで, 水質の流量 依存特性を把握し負荷量の推定を行った. 今回， CODについて1999年から2002年のデータから考察 すると, CODは同じ流量においても濃度が違うヒス テリシスの関係がみられ, 浮遊成分の影響を強く受 けていることが判った. また，イベントの最大流量 が増加すればするほどそのヒステリシスの同じ流量 における濃度の違いの幅が広がり, 流量(Q) - COD の勾配も最大流量が増加するほどなだらかになるこ とが判った(図-4). そして以下の2つの推定方法を提 案した.

1つ目は, CODの水質特性から5つの推定式(表-3) を導き出し,一年間の負荷量誤差について検討した. その結果, 2002年以外の3つの年において, 真值より 約 2 倍以上の過大評価がみられ, 流量が $1400 \mathrm{~m}^{3} / \mathrm{s}$ 末満 の現象から推定式を導き出したため, 流量が $1400 \mathrm{~m}^{3} / \mathrm{s}$ 以上の負荷量を高く推定してしまうことが 原因であると判った。
2つ目は,負荷量平均から推定式を導き推定後の負 荷量誤差について検討した. 流量が $100 \mathrm{~m}^{3} / \mathrm{s}$ 未満の基 底流量時のデータが多いと誤差がー $41 \%$ ，また， $1400 \mathrm{~m}^{3} / \mathrm{s}$ 以上のデータが多いと誤差が $48 \%$ に達した。 このことから，流量が $100 \mathrm{~m}^{3} / \mathrm{s}$ 以上 $1400 \mathrm{~m}^{3} / \mathrm{s}$ 末満の時 のCOD濃度がうまく推定できていることが判った. また,5つの推定式で推定した負荷量よりも精度が高 いことが示された。

精度の高い平均負荷量推定式から1970年から 2002 年までのCOD濃度を推定した結果, 負荷量推定にお いて高流量時のCOD濃度のばらつきが小さいと誤 差も小さくなることが判った。そして，1999年から 2002年の水質特性が変化していないと仮定し, 過去 の負荷量を推定した結果, 今回の結果では, 年によ ってCOD負荷量が最大 8 倍も異なることが判った。 最後に, 本論文で述べたCOD,TB,ECの流量依存性が 高いことは，他の河川，また同じ河川の上流，下流 においても普遍的ではなく, 負荷流出や流域の特性 によって変わると考えられ，どこまで適用できるか が今後の課題である.

\section{参考文献}

1）国土庁長官官房水資源部編：日本の水資源(平成8年版) 一水資源の有効利用一，大藏省印刷局，1996

2）國松孝男, 須戸幹 : 林地からの污濁負荷とその評価, 水環境学会誌, Vol.20 No12, 1997

3）荒木直哉, 井伊博行, 平田健正, 金子泰純, 平出純一, 川上義之 : 紀ノ川の物質負荷量の推定と土地利用との 関係, 水工学論文集, 第46巻, pp.241 246, 2002

4) 金子泰純, 井伊博行, 平田健正, 福島教之, 江種伸之, 谷川寛樹 : 紀ノ川の水質特性と土地利用の関係, 水工 学論文集, 第45巻, pp.1009 1014, 2001

5) 寉原拓馬, 井伊博行, 平田健正, 石塚正秀, 谷口正伸, 伊势達男, 宮川勇二 : 大和川流域における物質移動量 の推定, 水工学論文集, 第46巻, pp.229 234, 2002

6) 窪原拓馬, 井伊博行, 平田健正, 江種伸之, 石塚正秀, 伊势達男, 宮川勇二 : 大和川流域における河川水の水 質特性について, 水工学論文集, 第45巻, pp.985〜990, 2001

7) 井伊博行, 谷口正伸, 平田健正, 石塚正秀, 社原拓馬, 伊势達男, 宮川勇二 : 大和川の B OD, アンモニア態 窒素, 陰イオン界面活性剂濃度の季節変動とその原因 について, 水工学論文集, 第46巻, pp.235 240, 2002

8）紀の川Navi : http://www.kkr.mlit.go.jp/wakayama/kinokaw a/kinokawa.html

9）木下良作 : 航空写真による洪水流解析の現状と今後の 課題, 土木学会論文集, 第345号 II-1, 1984

10) 伊勢屋ふじこ: 茨城県桜川における浮遊土砂と河畔堆 積減少，第23回水理講演会論文集，1979

11）有田正光編著, 池田裕一, 中井正則, 中村由行, 道奥 康治, 村上和男共著: 水圈の環境, 東京電機大学, 1998

12）武田育郎著: 水と水環境の基礎知識, 株式会社オーム 社, 2001

(2003.9.30受付) 